\title{
An Optimal Energy Management System for PV/Battery Standalone System
}

\author{
Vellanki Mehar Jyothi, T. Vijay Muni, S V N L Lalitha \\ Department of Electrical and Electronics Engineering, K L University, Vaddeswaram, India
}

\begin{tabular}{l}
\hline \hline Article Info \\
\hline Article history: \\
Received Jun 8, 2016 \\
Revised Jun 29, 2016 \\
Accepted Jul 13, 2016 \\
\hline
\end{tabular}

Keyword:

Battery

Energy management

MPPT

PV system

Transformer buck conveter

\begin{abstract}
This paper presents an optimal energy management for PV/battery standalone system. The system comprises photovoltaic array, battery, inverter and AC loads. PV array is an uncontrollable source due to the variations in irradiations and temperature. To deliver the highest point to the load a maximum power point tracking technique is used. In synchronization with battery bank the system becomes controllable. Modes of operation of the system are defined by the battery bank. Modes of operation are based on the difference between supply and load demand. This paper project proposes an optimal energy management strategy to improve the performance of the PV system. The anticipated system performance is evaluated for varying loads in MATLAB/simulink.
\end{abstract}

Copyright $\odot 2016$ Institute of Advanced Engineering and Science. All rights reserved.

\section{Corresponding Author:}

T. Vijay Muni,

Department of Electrical and Electronics Engineering,

K L University,

Vaddeswaram, Guntur Dt, Andhra Pradesh-522502, India.

Email: vijaymuni@kluniversity.in

\section{INTRODUCTION}

Due to critical situation of fossil fuel declining and the global warming effect, alternative energies became popular. In nature many renewable energy resources are available like solar, wind, tidal and hydel. But solar energy is the most popular source among the alternative energy resource with out emission of pollutants energy conversion is done. Demand for solar energy is increased from $20 \%$ to $25 \%$ over the past 15 years. Other advantages of solar energy are like eco- friendly, abundant availability in nature. Power Electronics palys a major role in this energy management system [1-2]. A power Electronics converter converts the DC power from the PV source into AC power which is used to supply the local loads or to grid $[3-5]$.

Generally a PV cell has low energy conversion efficiency. Its voltage is about $0.5-0.8 \mathrm{~V}$, to track the maximum power from photovoltaic maximum power point tracing is essential. Since the PV energy source is discontinuous in nature, to supply power to the load continuously battery is added. Energy can be stored in the battery or it can supply thelocal load or grid [6-7]. It will define depending upon the different modes of operation. Energy balance between the supply energy and load determines the modes of operation. Bidirectional converter offers the advantages of reducing the no. of batteries used and also ensures the power flow even if one of the cells fails [8].

Energy Management system for controlling a Microgrid is presented in [9]. This paper presents management of power flow for minimizing the cost of electricity and reduction loss of energy produced by renewable energy sources.

Lagorse et al., [10] proposed an Energy Management System to control the energy flow in the microgrid which is composed by PV system, Fuel Cell, supercapacitor and load. 
Lu and Francois [11] presents an Energy Management System for a Microgrid based on the dayahead power scheduling, considering the power prediction and load forecasting.

PSO-Based energy mamagement system for a stansalone Microgrid is presented in [12]. In paper describes the optimal balance between generation units and also by incorporating desirable energy objectives into the EMS decision-making process. The modeling equations of the solar cell is shown in [13]

Transformer based isolated bidirectional converter is used the proposed system [14]. Lead-Acid battery is used in the proposed system because of its low cost and long life [15-19]. This paper presents best possible energy management strategy for PV/battery stand-alone system.

The proposed system performance is tested under various operational conditions and obtained results have good energy management characteristics. The rest of the paper is structured as follows: Section 2 discusses about the overall PV/Battery stasalone system description. Section $3 \& 4$ presents the modeling of the energy management system and different modes of operation respectively. Section 5 validats the proposed energy management control by the simulations results and Section 6 highlights the conclusions drawn from the results.

\section{SYSTEM DESCRIPTION}

Figure 1 shows the PV/Battery standalone system for energy management system.

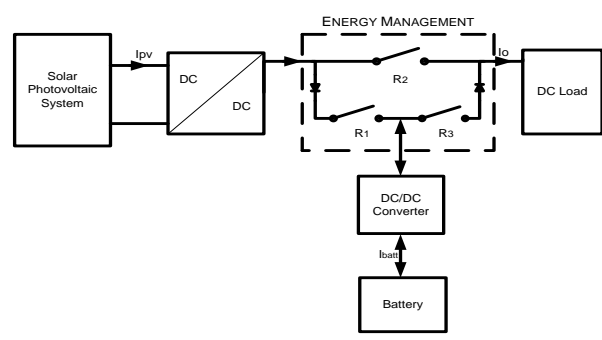

Figure 1. Proposed design of PV/Battery stand-alone system

It includes a Photovoltaic array with buck boost and transformer buck converters, batteries and variable DC load. Buck boost Converter, battery and load are connected through three relays. The proposed system main function is to manage the energy between PV, Battery and load. This energy management is done by the different modes of operation which are resolute by the energy balance between the generated energy and the load demand.

\section{MODELING OF PROPOSED SYSTEM}

\subsection{Dynamic Model of PV Array}

The PV array involves $\mathrm{N}$ strings of modules connected in parallel, and each string consists of $\mathrm{M}$ modules connected in series to obtain a suitable power rating. The dynamic model of PV cell is shown in Figure 2.

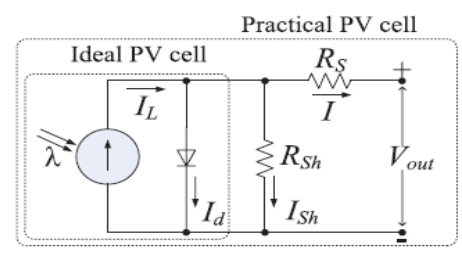

Figure 2. Equivalent electrical circuit for PV cell

The series resistance $R_{S}$ represents the internal resistance to the current flow. The shunt resistance $R_{S h}$ is inversely related to leakage current to the ground. For an ideal PV cell, $R_{S}=0$ (no series loss) and $R_{\mathrm{Sh}}=$ infinite (no leakage to ground). The typical values of $R_{S}=0: 05$ to $0.10 \Omega$ and $\mathrm{R}_{S h}=200$ to $300 \Omega$. The energy 
conversion efficiency of PV cell is sensitive to small variations in $R_{S}$, but is insensitive to variations in $\mathrm{R}_{S h}$. A small increase in $R_{S}$ can decrease the PV output significantly.

The process of modeling of solar cell is developed based on the following equations [13]. The output-terminal current $\mathrm{I}$ is equal to

$$
I=I_{p h}-I_{d}-I_{s h}
$$

where,

$\mathrm{I}_{p h}$, Light generated current

$\mathrm{I}_{d}$. Diode Current

$\mathrm{I}_{s h}$, Shunt Leakage current

$$
I=I p h-I_{o, \text { cell }} * e^{\frac{q * v}{\alpha k T}}-1
$$

where,

$\mathrm{I}_{\mathrm{o}, \text { cell }}$ : Reverse saturation current of the diode[A].

q: Electron charge $\left[1.60217646 \times 10^{-19} \mathrm{c}\right]$.

$\mathrm{k}$ : Boltzmann constant $\left[1.3806503 \times 10^{-23} \mathrm{~J} / \mathrm{k}\right]$.

$\mathrm{T}:$ Temperature of the $\mathrm{p}-\mathrm{n}$ junction.

$\alpha$ : Diode identity factor which lies between $1 \& 2$ for mono crystaline silicon.

\subsection{MPPT During DC-DC Conversion}

The PV cell produces the maximum power at voltage corresponding to the knee point of the $I-V$ curve, as shown in Figure 3.

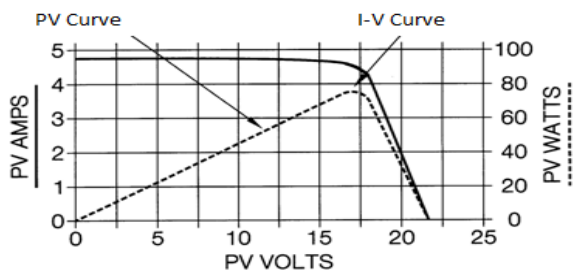

Figure 3. MPPT System

$V_{\max }$ and $I_{\max }$ are maximum power point voltage and current, respectively. The dc-dc converter is set to operate at optimal voltage to achieve maximum power by MPPT algorithm. In this system Perturb and Observe (P\&O) method is used to track the MPP from PV cell.

$\mathrm{P} \& \mathrm{O}$ measures and operates by increasing or decreasing the array terminal voltage, or current, at regular intervals and then comparing the PV output power with that of the previous sample point. If the PV array operating voltage changes and power increases $(d P / d V, \mathrm{PV}>0)$, the control system adjust the PV array operating point in that direction; otherwise the operating point is moved in the opposite direction.

\subsection{Electrical Model of Battery}

Battery is an important element of a stand-alone PV system due to the fluctuating nature of PV array. Lead acid battery is used due to its performance characteristics [19] as shown in Figure 4.

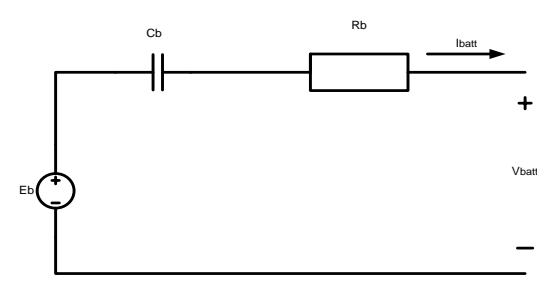

Figure 4. Equivalent Circuit of Battery. 
Electromagnetic force is kept in series with the source voltage $E_{b}$. Internal resistance $R_{b}$. The terminal voltage of the battery is given by:

$$
V_{\text {batt }}=E_{b}-R_{b} * I_{b a t t}-V_{c b}
$$

State of charge of the battery is given in the equation below:

SOC is the amount of electricity stored during the charge.

$$
S O C=1-\frac{Q_{d}}{C_{\text {batt }}}=1-\frac{I_{\text {batt }} * t}{C_{\text {batt }}}
$$

where,

$\mathrm{Q}_{\mathrm{d}}$ : ampere-hours stored in the battery during a time $\mathrm{t}$ with a charging current $\mathrm{I}_{\text {batt }}$. $\mathrm{C}_{\text {batt }}$ : battery nominal capacity.

\subsection{Bidiectional DC-DC Converter}

Transformer based isolated bidirectional converter is shown in Figure 5.

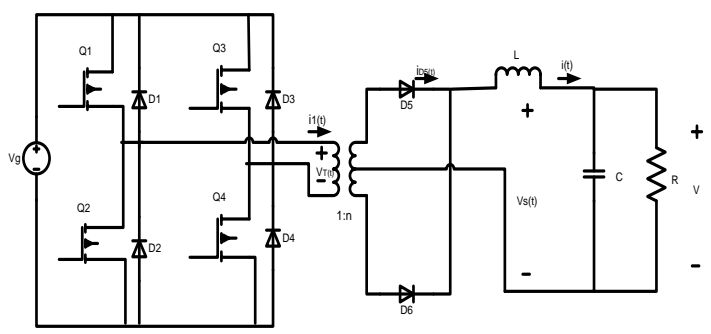

Figure 5. Transformer Based Isolated DC-DC Converter

Isolated buck is used due to its advantages over other converters. It has the following features. To convert the energy storage system to the bus. It is able to operate under a wider output power range. Bidirectional power flow, high power operation, galvanic isolation, long battery life time. A long battery life time is achieved by draining from and providing to the battery a low ripple DC Current.

\section{MODES OF OPERATION OF PROPOSED SYSTEM}

The energy management is done between the PV system, Battery and Load. This management system controls the energy produced by the PV array and battery storage to supply the demand [21-22].

\subsection{Operating Modes}

The proposed PV/Battery stand alone system operates in any one of the five modes.

Mode 1: $\mathrm{P}_{\mathrm{PV}}>\mathrm{P}_{\text {load }}$ (Battery Chargig) : In this mode PV system generates excess amount of power than the demand. At this time battery is charging with remaining power.

Mode 2: $\mathrm{P}_{\mathrm{PV}}<\mathrm{P}_{\text {load }}$ (Battery Discharging): In this mode $\mathrm{PV}$ system generates insufficient power and the required amount of power is taken from the battery.

Mode 3: $\mathrm{P}_{\mathrm{PV}}=0$ (Battery supplies to load): When there is no available energy from the PV then Battery supplies the load

Mode 4: $\mathrm{P}_{\mathrm{PV}}=\mathrm{P}_{\text {load }}$ (Only PV supplies to load): In this mode the PV array generate sufficient energy to feed the load without the interference of battery.

Mode 5: $\mathrm{P}_{\mathrm{PV}}=0, \mathrm{P}_{\text {batt }}=0$ (Disconnect the load) In this mode, no $\mathrm{PV}$ energy production and battery is completely discharged, then the consumer is disconnected.

\subsection{Simulation Circuit Diagram}

Figure 6 shows the simulation diagram for proposed energy management system. The proposed system consists of PV aray, Battery and Energy Management System. PV array system will act as a source and battery will charge and discharge depending on the load. This energy management is done by the 
different modes of operation which are resolute by the energy balance between the generated energy and the load demand.

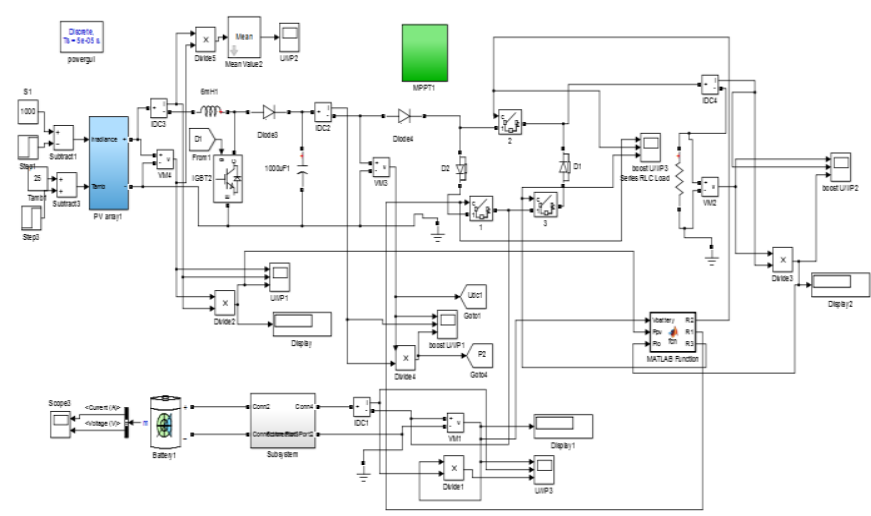

Figure 6. Simulation Diagram for Proposed System

\subsection{Proposed Algorithm for Energy Management System}

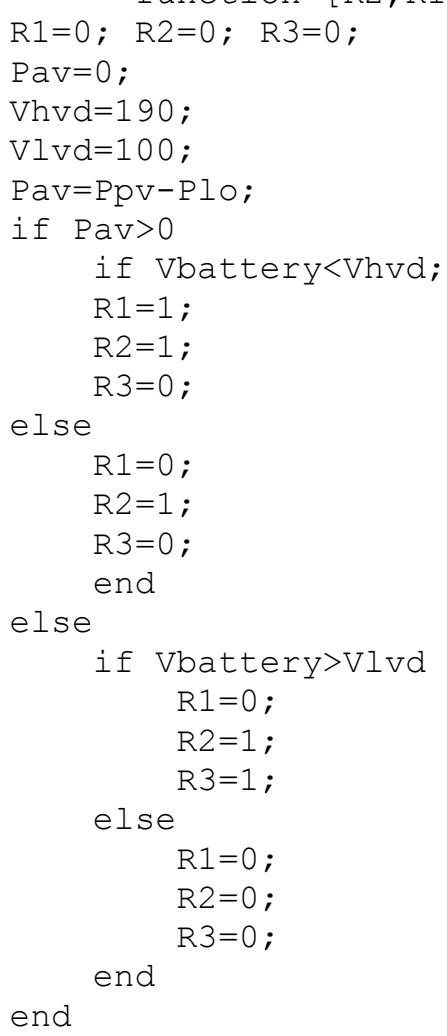

\section{SIMULATION RESULTS}

The Figure. 7 shows the power-time characteristics, where the rise time is from 0 to $0.2 \mathrm{sec}$, transient state starts from 0.2 to $0.6 \mathrm{sec}$ and from 0.6 to 1 it shows the steady state.

Load characteristics are shown in the Figure 8 where the curves are plotted between Voltage and time, current and time, power and time. The raise time is from 0 to 0.11 , transient state is from 0.12 to $0.5 \mathrm{sec}$ and the steady state characteristics are from 0.5 to $1 \mathrm{sec}$ as shown here. 


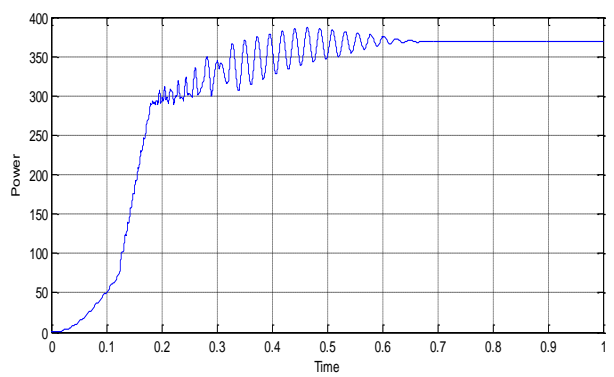

Figure 7. PV Power v/s Time
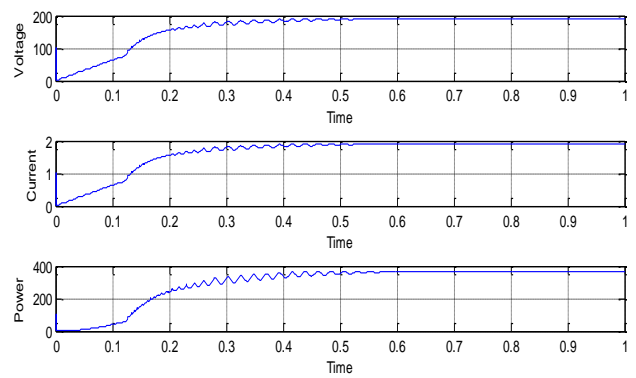

Figure 8. Load Characteristics

Figure 9 shows PV characteristics which are plotted between the Voltage and time, current and time, power and time. The rise time is from 0 to 0.14 , transient state is from 0.15 to $0.6 \mathrm{sec}$ and the steady state characteristics are from 0.61 to $1 \mathrm{sec}$ shown here.

Figure 10 shows characteristics of DC Converter, which are plotted between the Voltage and time, current and time, power and time. The raise time starts from 0 to 0.14 , transient state is from 0.15 to $0.7 \mathrm{sec}$ and the steady state characteristics are from 0.7 to $1 \mathrm{sec}$ shown here.

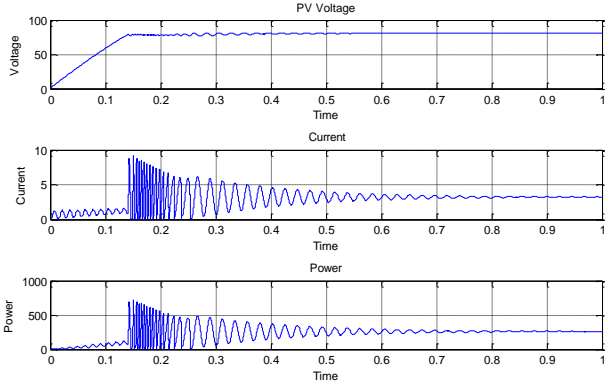

Figure 9. PV Characteristics
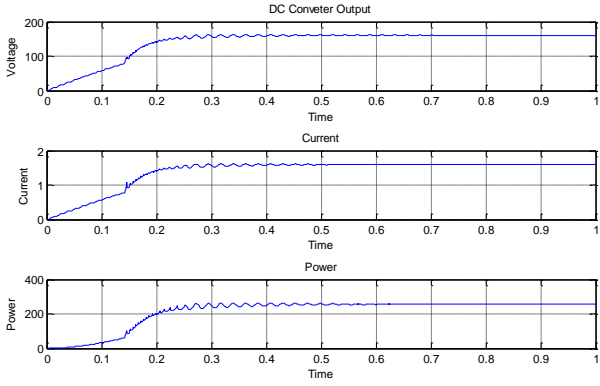

Figure 10. DC Converter Output

\section{CONCLUSION}

An optimal energy management algorithm was developed for PV/battery stand-alone system. The algorithm has capable to manage and organize the different modes of operation. The modeling of PV cell is studied with the MPPT technique. Battery is connected with bi-directional DC-DC converter to compensate the load. The simulation result shows the energy management algorithm will operate correctly for the battery charging and discharging and in compensation of the load demand.

\section{REFERENCES}

[1] S.K. Kim, J.H. Joen, C.H. Cho, J.B. Ahn, and H Kwon, Dynamic modelling and control of a grid-connected hybrid generation system with versatile power transfer, IEEE Trans. Ind. Electron., vol. 55, no. 4, p. 1677-1688, Apr. 2008.

[2] F. Valenciaga and P.F. Puleston, Supervisor control for a stand-alone hybrid generation system using wind and photovoltaic energy, IEEE Trans. Energy Conv., vol. 20(2), p. 398-405, June 2005.

[3] Hamrouni N, Jraidi M, Chérif A. New control strategy for 2-stage grid connected photovoltaic power system. Renewable Energy, 2008; 33(10):p. 2212-21.

[4] Barbosa PG, Rolim LGB, Watanabe EH, Hanitsch R. Control strategy for grid connected DC-AC converters with load power factor correction. IEEE Procedings. Gener, Transm Distrib, 1998; 145(5): p. 487- 492.

[5] Koutroulis E, Kalaitzakis K, Voulgaris NC., Development of a microcontroller based, photovoltaic maximum power point tracking control system. IEEE Transactions on Power Electronics, 2001; 16(1): p. 46-54.

[6] Boucetta Abd Allah, Labed Djamel, Control of Power and Voltage of Solar Grid Connected. International Journal of Electrical and Computer Engineering (IJECE), Vol. 6, No. 1, February 2016, pp. 26 33.

[7] Use of Photovoltaics in Microgrid as Energy Source and Control Method using MATLAB/Simulink, International Journal of Electrical and Computer Engineering (IJECE), Vol. 6, No. 2, April 2016, pp. 851 858.

[8] http://www.batteryuniversity.com/partone-24.htm 
[9] R.J. Wai and R.Y. Duan, High-efficiency bidirectional converter for power sources with great voltage diversity, IEEE Trans. Power Electron, vol. 22, no. 5, p. 1986-1996, Sep. 2007.

[10] C. Marisarla and K.R. Kumar, "A Hybrid Wind and Solar Energy System with Battery Energy Storage for an Isolated System, International Journal of Engineering and Innovative Technology (IJEIT), vol.3, no. 3, p. 99-104, September 2013

[11] S.W. Mohod and M.V. Aware, Micro Wind Power Generator With Battery Energy Storage for Critical Load, IEEE Systems Journal, vol. 6, no. 1, p. 118-125, March 2012.

[12] C.A. Hill, M.C. Such, D. Chen, J. Gonzalez and W.M. Grady, Battery Energy Storage for Enabling Integration of Distributed Solar Power Generation, IEEE Transactions on Smart Grid, vol. 3, no. 2, p.850 - 857, June 2012.

[13] Matthew Clayton Such, Cody Hill, "Battery Energy Storage and Wind Energy Integrated into the Smart Grid", IEEE PES Innovative Smart Grid Technologies (ISGT'12), p. 1-4, January 2012.

[14] J.F. Manwell and J.G. McGowan, Lead Acid Battery Storage Model for Hybrid Energy Systems, Solar Energy, vol. 50, no. 5, p. 399-405, 1993.

[15] Lombardi, P., Powalko, M., Rudion, K., Optimal operation of a virtual power plant, IEEE Power \& Energy Society General Meeting, 2009.

[16] Lagorse, J., Somoes, M., A multiagent fuzzy-logic- based energy managment of hybrid systems, IEEE Industry Applications Society Annual Meeting (IAS), 2009.

[17] Lu, D., Francois, B., Strategic framework of an energy management of a microgrid with a photovoltaic-based active generator, ELECTROMOTION, 2009

[18] Pourmousavi S.A., Nehrir M.H., Colson C.M., Wang, C., Real-time energy management of a stand-alone hybrid wind-microturbine energy system using particle swarm optimization, IEEE Transactions on Sustainable Energy, 2010

[19] Lalouni S, Rekioua D, Rekioua T, Matagne E, "Fuzzy logic control of Standalone photovoltaic system with Battery Storage”, Journal of Power Sources, vol. 193, no. 2, pp. 899-907, 2009.

[20] Akassewa Tchapo SINGO, "Système d'alimentation photovoltaïque avec stockage hybride pour l'habitat énergétiquement autonome", Doctorat Theses Nancy-I, 2010.

[21] S. Sallem, M.Chaabene, M.B.A.Kamoun, "Energy management algorithm for anoptimum control of a photovoltaic water pumping system”. Applied Energy, vol.86, pp.2671-2680, 2009.

[22] I. Yahyaoui, S. Sallem, M.B.A. Kamoun, F. Tadeo, "Fuzzy energy management of an off-grid PV/Battery system", In Proceeding of the fourth international Renewable Energy Congress, pp. 779-786, 2012. 